\title{
Türkiye'nin Göreli Atıf Etkisi Üzerine Bilimetrik Bir Çalışma
}

\section{A Scientometric Study on Relative Citation Impact of Turkey}

\author{
Umut $A L^{*}$
}

\begin{abstract}
Öz
Türkiye'nin atıf dizinlerine yaptığı katkı her geçen yıl artış göstermektedir. Özellikle Türkiye adresli dergilerin bir kısmının atıf dizinleri kapsamına alınması, bu artışı daha da belirgin kılmıştır. Bu artışta, kâr amaçıı bir yapı olduğu herkesçe bilinen atıf dizinlerinin sahibi ticari kurumun almış olduğu genişleme kararının önemli rolü bulunmaktadır. Bu çalışmada Türkiye'nin göreli atıf etkisi açısından bir değerlendirmesi yapılmakta, ülkeler ve alanlar bazında çeşitli karşılaştırmalara yer verilmektedir. Çalışmanın verileri Essential Science Indicators adlı kaynaktan elde edilmiştir. Araştırmamız, Türkiye'nin göreli atıf etkisi yüksek ve düşük alanlarını belirlemeyi, zaman içinde Türkiye'nin farklı alanlardaki göreli atıf etkisinin değişip değişmediğini ve farklı ülkelerle karşılaştırıldığında Türkiye'nin göreli atıf etkisi bakımından konumunu ortaya koymaya çalışmaktadır. Bulgular, Türkiye'nin göreli atıf etkisi en yüksek alanının mühendislik, en düşük alanının ise bitki ve hayvan bilimleri olduğunu göstermektedir. Öte yandan Türkiye'nin göreli atıf etkisi yüksek alanları ile düşük alanları arasında zaman içinde önemli bir değişim olduğu gözlenmemiştir. Amerika Birleşik Devletleri hemen her alanda bilim dünyasındaki tartışılmaz egemen konumunu sürdürmektedir. Türkiye ise henüz Ingiltere, Almanya, Kanada, Fransa gibi ülkelerle yarışabilecek düzeye ulaşamamıştır.
\end{abstract}

Anahtar sözcükler: Göreli atıf etkisi, Bilimetri, Bibliyometri, Türkiye adresli yayınlar

\begin{abstract}
Turkey's contribution to citation indexes has been increasing every year. This increase has become particularly visible with the inclusion of some of the Turkey addressed journals in the citation indexes. The expansion decision taken by the commercial company that owns citation indexes also plays a significant role in this increase. This study evaluates the relative citation impact of Turkey and includes various comparisons based on country and field of study data. The data used in this study is obtained from Essential Science Indicators. The aim of the study is to examine Turkey's high and low relative citation impact areas and determine whether there is a change in relative citation impact in time. Our study also tries to expose Turkey's position in terms of relative citation impact when
\end{abstract}

\footnotetext{
* Dr.; Hacettepe Üniversitesi Edebiyat Fakültesi Bilgi ve Belge Yönetimi Bölümü, Beytepe Ankara. (umutal@hacettepe.edu.tr)
} 
compared with different countries. The findings indicate that engineering is the highest relative citation impact area in Turkey and plant and animal sciences is the lowest, and no significant changes are observed between the two in time. The United States of America preserves its indisputable leading position in all areas in the scientific world. Turkey, on the other hand, is yet to reach to a level, where it can compete with such countries as England, Germany, Canada and France.

Keywords: Relative citation impact, Scientometrics, Bibliometrics, Turkey adressed publications

\section{Giriş}

Bibliyometri ve bilimetri terimleri bilimin ve bilimsel yayınların değerlendirilmesine yönelik olarak sıklıkla kullanılmaktadır. Bilimetri bilim dallarının analizi ile ilgilenirken, bilimsel yayınlara ilişkin değerlendirilmelerde bibliyometriden yararlanılmaktadır. Birçok araştırmacı ise zaten bu terimlerin birbirleriyle yakından ilgili olduklarını ve çoğu kez birlikte kullanıldıklarını ifade etmektedir (Björneborn, 2004, s.14; Tague-Sutcliffe, 1992, s.1). Son yıllarda, genel olarak bilimin, özel olarak ise bilim dallarının ve bilim insanlarının değerlendirilmesine dayalı analizlerin sayısında önemli düzeyde artış olduğu gözlenmektedir. Bu artışın en önemli nedenlerinden birisi performansa bağlı olarak değerlendirmelerin her geçen gün önem kazanmasıdır.

Gelişen bilgisayar olanakları büyük oylumlu veri setleri ile çalışmayı kolaylaştırmış, atıf dizinlerine dayalı verilerden çevrimiçi olarak yararlanılabilmesi de, araştırmacıların büyük verileri standart şekilde elde edebilmelerini sağlamıştır. Doğal olarak bu durum yukarıda sözü edilen analizlerin sayısının artmasının bir başka nedenidir. Bu bağlamda belli bir alana yönelik olarak, ülkeler arasında yapılan karşılaştırmalar araştırmacıların daha az zamanını almaktadır. Söz konusu karşılaştırmalar farklı göstergelerden (yayın başına düşen atıf sayısı, $h$-endeksi gibi) yararlanılarak yapılmakta ve değerlendirmelerde öne çıkan ülkelerin bilimsel saygınlığını olumlu yönde etkilemektedir.

Göreli atıf etkisi, bir ülkenin aynı zaman aralığında bir konu alanındaki yayın başına ortalama atıf oranının dünyada ilgili alandaki yayın başına ortalama atıf oranına bölünmesi sonucu elde edilen bir değerdir. Bir ülkeye ait göreli atıf etkisinin 1'den küçük olması, söz konusu alanda o ülkenin dünya ortalamasının altında kaldığını göstermektedir. Göreli atıf etkisinin 1 olduğu durumlarda ise, söz konusu alanda dünya ortalaması ile aynı düzeyde atıf elde edildiği anlaşılmaktadır (Braun, 1999, s.428; Katz, 2000, s.24). $\mathrm{Bu}$ araştırmada, Essential Science Indicators (ESI) verilerinden yararlanılarak çeşitli alanlardaki Türkiye'nin atıf performansı incelenmektedir.

\section{Önceki Çalışmalar}

Bilimetri ile ilgili göstergelerin araştırmaların değerlendirilmesinde kullanılması ilk olarak 1960 ve 1970'li yıllarda ABD'de başlamış, daha sonra birçok Avrupa ülkesinde benzer yönde çalışmalar gerçekleştirilmiştir (Leydesdorff, 2005, s.1510). Bu bağlamda göreli atıf etkisi birçok araştırmacının ilgilendiği bir konu olarak 1980’li yıllar ile birlikte araştırmacıların 
gündemine girmiştir. Özellikle belli bir grubun yaptığı çalışmalar bu alanda öncü olmuştur (Braun, Glänzel ve Schubert, 1987a, 1987b, 1987c, 1988a, 1988b, 1988c, 1989). Söz konusu çalışmalarda, ülkeler arasında, belli disiplinlerde karşılaştırmaların yapıldığı görülmektedir. Öte yandan göreli atıf etkisi ile bazı bibliyometrik göstergeler arasındaki ilişkileri araştıran çalışmalar da bulunmaktadır. Bu çalışmalardan birinde kendine atıf oranı yüksek olan ülkelerin göreli atıf oranının düşük olduğu sonucu elde edilmiştir (Glänzel, Thijs ve Schlemmer, 2004). Başka bir çalışma, uluslararası işbirliği sonucu üretilmiş yayınları çok olan ülkelerin, yayınları ortak çalışma sonucu çıkmayan ya da kendi ülke sınırları içerisinde ortaklaşa yayın faaliyeti içinde bulunan ülkelere göre daha yüksek göreli atıf etkisine sahip olduğunu işaret etmektedir (Butler, 2003, s.147).

Ülkelerin göreli atıf etkisinde zaman geçtikçe değişim olup olmadığını inceleyen çalışmalar da literatürdeki yerini almıştır (Ingwersen 2000; May 1997; Persson, Luukkonen ve Hälikkä 2000). Bu çalışmalarda, dünya atıf ortalamalarından yola çıkılarak ülkelere ait yayınların etkisi zaman değişkeni kullanılmak suretiyle ortaya konulmaktadır. Söz konusu çalışmalarda kimi zaman belli bir yıl aralığı başka bir yıl aralığı ile karşılaştırılmakta, kimi zaman ise değişimin boyutları yıl yıl incelenmektedir.

Uzun yıllardır Essential Science Indicators ve National Science Indicators verilerine dayanılarak Science Watch** adı altında ülkelere yönelik karşılaştırmalara yer verilmektedir. Farklı alanlarda ve farklı zamanlarda yapılan değerlendirmelerde ABD'nin göreli atıf etkisinin her zaman 1'den büyük olduğu saptanmıştır (King 2009; May, 1997; SCl-Bytes, 2003).

Türkiye'de konu ile ilgili çalışmaların son yıllarda gündeme geldiği görülmektedir. Özellikle iki öğretim üyesinin 2547 sayılı Yükseköğretim Kanununun 38. maddesi çerçevesinde Türkiye'nin bilim göstergelerine yönelik bir analiz gerçekleştirmek amacıyla YÖK tarafından görevlendirilmesi ve hazırladıkları raporda Türkiye'nin göreli atıf etkisinin tüm alanlarda dünya ortalamasının altında olduğunun saptanması önemlidir (Karasözen ve Bayram, 2007). Ayrıca söz konusu çalışmada ISı veri tabanına göre üniversitelerin yayın ve atıf performansları ile uluslararası ortak yazarlı yayınlar incelenmekte, yayınların dergi etki faktörlerine göre değerlendirilmesi de yapılmaktadır.

Son olarak Türkiye'nin bilimsel yayın politikası üzerine yapılan bir doktora çalışması (Al, 2008) göreli atıf etkisi ile ilgili bulgular içermektedir. Söz konusu çalışmada bütün alanlarda Türkiye'nin göreli atıf etkisinin 1'den düşük olduğu kaydedilmektedir. Çalışmada Türkiye'nin göreli atıf etkisi en yüksek üç alanının mühendislik, yer bilimleri ve bilgisayar bilimleri olduğu ortaya çıkmıştır (Al, 2008, s.112). Bununla birlikte çalışma kapsamında çeşitli açılardan yapılan değerlendirme ve karşılaştırmalarda Türkiye adresli yayınlara ilişkin, aralarında göreli atıf etkisinin de bulunduğu kimi göstergelerin ülke potansiyelini yansıtmadığı sonucuna varılmıştır (Al, 2008, s.130).

** Çeşitli ülkelere ve çeşitli alanlara yönelik analizlere http://www.sciencewatch.com/ adresinden erişilebilir. 


\section{Yöntem}

Araştırmamızın amacı Türkiye'nin çeşitli alanlardaki araştırma etkisine ilişkin durumunu bilimetrik bir gösterge olan göreli atıf etkisini kullanarak sunmaktır. Ayrıca daha önce yapılmış bir çalışmada (Al, 2008) kullanılan veriler aracılığıyla geçen zaman içindeki değişim incelenmektedir.

Çalışmamızda, ESı adlı kaynaktan yararlanılmıştır. Söz konusu kaynak dergilere, ülkelere, kurumlara ve bilim insanlarına yönelik olarak atıflarla ilgili veriler içermektedir. ESl'de 22 araştırma alanı ve bu alanlara ait 10 yıllık bir zaman dilimini içeren veriler bulunmaktadır. Söz konusu araştırma alanları, bilgisayar bilimleri, bitki ve hayvan bilimleri, biyoloji ve biyokimya, çevre ve ekoloji, çok disiplinli bilimler, ekonomi ve işletme, farmakoloji, fizik, immünoloji, kimya, klinik tıp, malzeme bilimi, matematik, mikrobiyoloji, moleküler biyoloji ve genetik, mühendislik, nöroloji, psikiyatri ve psikoloji, sosyal bilimler, uzay bilimleri, yer bilimleri ve ziraat şeklinde sıralanmaktadır. Çalışmamız çok disiplinli bilimler dışında kalan 21 alanı kapsamaktadır. Çok disiplinli bilimlere çalışma kapsamında yer verilmemesi bu alandaki yayın sayısının fazla olmamasından kaynaklanmaktadır. Literatürde de benzer şekilde bu alanın değerlendirilmeye alınmadığı örnekler bulunmaktadır (Czajbók, Berhidi, Vasas ve Schubert, 2007).

Çalışmamızda elde edilen veriler, zaman içinde bir değişimin olup olmadığını görmek için daha önce gerçekleştirilmiş bir başka çalışmanın (AI, 2008) verileri ile de karşılaştırılmaktadır. Daha önceki çalışmada kullanılan veriler 15 Eylül 2005 tarihinde elde edilmiştir ve 1 Ocak 1995 - 30 Haziran 2005 arasına aittir. Bu çalışmadaki veriler ise 1 Ocak 1999 - 28 Şubat 2009 tarihleri arasındaki yayınlara aittir ve 10 Haziran 2009 tarihinde yapılan tarama sonucunda elde edilmiştir. Veri tabanındaki atıflara yönelik güncelleme ise ESI tarafından 1 Mayıs 2009 tarihinde yapıımıştır.

Araştırmamızda genel olarak yanıt aranan sorular şunlardır:

$\diamond \quad$ Türkiye'nin göreli atıf etkisi yüksek ve düşük alanları hangileridir?

$\diamond \quad$ Zaman içinde Türkiye'nin farklı alanlardaki göreli atıf etkisi değişmiş midir?

$\diamond \quad$ Farklı ülkelerle karşılaştırıldığında Türkiye'nin göreli atıf etkisi bakımından konumu nedir?

Çalışmamızda veri kaynağının ESI olması birtakım sınırlamaları da beraberinde getirmektedir. İlk olarak çalışma kapsamındaki alanlar ESı tarafından saptanmış alanlardır ve bu durum birçok alan için yapılan değerlendirmelerin genel olmasına neden olmaktadır. Örneğin ESl'de sosyal bilimler tek bir başlık altında toplanmakta, alt disiplinler bazında değerlendirme ve yorum yapılamamaktadır. Bu nedenle alt disiplinlere ait değerlendirmeler için daha rafine verilere gereksinim duyulmaktadır. Ancak araştırmada, Türkiye'nin göreli atıf etkisi bakımından zaman içinde değişim olup olmadığı ve diğer ülkelerle karşılaştırıldığında konumunun ne olduğu gibi soruların yanıtlarının arandığı düşünüldüğünde, bu durum sorun teşkil etmemektedir. Aynı 
şekilde çalışma için bir sorun teşkil etmemekle birlikte, ESI kapsamındaki yayınların doküman türlerinin atıf dizinlerindeki tüm yayınları içermediği de dikkate alınmalıdır. Örneğin atıf veri tabanlarında editöre not ya da bildiri özeti olarak dizinlenen yayınlar bu çalışmanın kapsamı dışındadır.

\section{Bulgular ve Yorum}

ESI verileri genel olarak incelendiğinde Türkiye'nin yayın sayısı bakımından 21. sırada yer aldığı görülmektedir. Öte yandan ilk 30 ülke arasında ortalama atıf sayısına göre yapılan sıralamada Türkiye az bir farkla Rusya'nın önünde yer alarak 29. sırada bulunmaktadır. Bilimsel yayın sıralamalarında baskın ülke olma özelliğini sürdüren ABD'nin on yıllık zaman dilimini kapsayan yayınlarının almış olduğu atıf sayısı yaklaşık 40 milyondur ve atıf sayısı bakımından da oldukça yüksek bir ortalamaya (yayın başına 14 atıf) sahiptir (Bkz. Tablo 1).

Elimizdeki veriler Türkiye'nin hem yayın sayısında bir artış olduğunu, hem de yayın sayısına göre yapılan ülkeler sıralamasında gelişme kaydettiğini göstermektedir. Türkiye, daha önce ( $\mathrm{Al}, 2008$, s.107) yayın sayısı bakımından önünde yer alan İsrail, İskoçya, Danimarka, Finlandiya ve Avusturya'yı geçen zaman içinde geride bırakmıştır. Tablo 1'de yayın sayısı bakımından Türkiye'nin önünde yer alan ülkelerin tamamı daha önce de atıf dizinleri kapsamındaki dünya bilim literatürüne Türkiye'den daha fazla katkı sağlamış ülkelerdir.

Tablo 2'de Türkiye'nin dünya literatürüne yaptığı katkı alanlar bazında sunulmaktadır. Buna göre, Türkiye'nin dünya literatürüne en fazla katkıda bulunduğu alan klinik tıptır. Araştırmamız kapsamındaki dönemde klinik tıp alanında yapılan 1.896.937 yayının 42.011'i Türkiye adreslidir. Daha önceki çalışmada da Türkiye'nin en fazla katkısının klinik tıp alanında olduğu belirtilmektedir (Al, 2008, s.105). Bununla birlikte Türkiye'nin ilgili alandaki katkısının arttığı ve \%1,4'ten \%2,2'ye yükseldiği saptanmıştır. Diğer alanlarda da Türkiye'nin dünya literatüründeki payı artış göstermektedir. Türkiye'nin yayın sayısının artmasında akademik çevrelerin atıf dizinleri kapsamında yayın yapılmasına verdiği önemin rolü büyüktür. Buna ek olarak TÜBITAK'ın teşvikleri belli grupların ilgisinin devam etmesine neden olmaktadır. Uluslararası Bilimsel Yayınları Teşvik Programı kapsamında hem 2007 hem de 2008 yıllarında 12.000 'den fazla araştırmacı söz konusu teşvikten yararlanmıştır (ULAKBIM 2009). Yakın zamanda atıf dizinlerine giren Türkiye orijinli dergi sayısının artması da kısmen literatüre katkı oranlarını artıran bir etmendir. 
Tablo 1. ES/ verilerine göre en çok yayın yapan ülkeler ve atıf sayıları

\begin{tabular}{|c|c|c|c|}
\hline Ülke & Yayın sayısı & Atıf sayısı & $\begin{array}{c}\text { Ortalama atıf } \\
\text { sayısı }\end{array}$ \\
\hline Amerika Birleşik Devletleri & 2.842 .255 & 39.987 .564 & 14,07 \\
\hline Japonya & 758.764 & 6.837 .347 & 9,01 \\
\hline Almanya & 732.911 & 8.409 .979 & 11,47 \\
\hline İngiltere & 652.095 & 8.385 .007 & 12,86 \\
\hline Çin Halk Cumhuriyeti & 599.298 & 2.880 .768 & 4,81 \\
\hline Fransa & 525.128 & 5.631 .061 & 10,72 \\
\hline Kanada & 403.263 & 4.645 .436 & 11,52 \\
\hline İtalya & 384.287 & 3.924 .702 & 10,21 \\
\hline İspanya & 288.577 & 2.589 .912 & 8,97 \\
\hline Avustralya & 261.235 & 2.709 .128 & 10,37 \\
\hline Rusya & 261.056 & 1.078 .744 & 4,13 \\
\hline Hindistan & 237.103 & 1.112 .772 & 4,69 \\
\hline Hollanda & 224.614 & 3.036 .523 & 13,52 \\
\hline Güney Kore & 222.488 & 1.318 .397 & 5,93 \\
\hline İsveç & 167.176 & 2.150 .929 & 12,87 \\
\hline İsviçre & 163.161 & 2.402 .195 & 14,72 \\
\hline Brezilya & 161.769 & 903.285 & 5,58 \\
\hline Tayvan & 145.288 & 847.009 & 5,83 \\
\hline Polonya & 131.120 & 766.166 & 5,84 \\
\hline Belçika & 122.476 & 1.428 .814 & 11,67 \\
\hline Türkiye & 116.296 & 480.900 & 4,14 \\
\hline İsrail & 105.103 & 1.153 .465 & 10,97 \\
\hline İskoçya & 101.811 & 1.359 .882 & 13,36 \\
\hline Danimarka & 88.472 & 1.219 .245 & 13,78 \\
\hline Avusturya & 85.522 & 956.342 & 11,18 \\
\hline Finlandiya & 82.658 & 995.738 & 12,05 \\
\hline Yunanistan & 71.189 & 492.508 & 6,92 \\
\hline Meksika & 64.985 & 385.834 & 5,94 \\
\hline Norveç & 61.858 & 674.874 & 10,91 \\
\hline Çek Cumhuriyeti & 57.296 & 377.910 & 6,60 \\
\hline
\end{tabular}

Not: Ülkeler yayın sayılarına göre sıralanmaktadır.

Bilgisayar bilimleri, matematik, nöroloji, biyoloji ve biyokimya, fizik, ekonomi ve işletme, mikrobiyoloji, psikiyatri ve psikoloji, sosyal bilimler, immünoloji, moleküler biyoloji ve genetik ile uzay bilimleri Türkiye'nin dünya literatürüne yaptığı katkının \%1'den düşük olduğu alanlardır. Hemen hemen her alanda en fazla yayın ABD orijinlidir. ABD malzeme bilimi dışındaki tüm alanlarda en fazla katkıyı sağlayan ülke konumundadır. Malzeme biliminde ise Çin Halk Cumhuriyeti \%17'lik katkıyla ABD’nin (\%16) önünde yer almaktadır. 
Tablo 2. ESI'deki alanlara göre Türkiye'nin dünya literatüründeki payı

\begin{tabular}{|l|r|r|r|c|}
\hline Alan & $\begin{array}{c}\text { Toplam } \\
\text { yayın sayısı }\end{array}$ & $\begin{array}{c}\text { Türkiye'nin } \\
\text { yayın sayısı }\end{array}$ & $\begin{array}{c}\text { Katkı oranı } \\
\mathbf{( \% )}\end{array}$ & $\begin{array}{c}\text { Alandaki } \\
\text { katkı } \\
\text { sıralaması }\end{array}$ \\
\hline Klinik tıp & 1.896 .937 & 42.011 & 2,215 & 13 \\
\hline Ziraat & 175.686 & 3886 & 2,212 & 14 \\
\hline Mühendislik & 730.267 & 11.790 & 1,614 & 16 \\
\hline Bitki ve hayvan bilimleri & 509.778 & 8082 & 1,585 & 20 \\
\hline Çevre ve ekoloji & 234.223 & 3342 & 1,427 & 23 \\
\hline Farmakoloji & 165.667 & 2282 & 1,377 & 20 \\
\hline Malzeme bilimi & 414.073 & 5181 & 1,251 & 19 \\
\hline Kimya & 1.099 .320 & 12.011 & 1,093 & 21 \\
\hline Yer bilimleri & 254.530 & 2578 & 1,013 & 25 \\
\hline Bilgisayar bilimleri & 247.585 & 2205 & 0,891 & 26 \\
\hline Matematik & 229.831 & 2037 & 0,886 & 25 \\
\hline Nöroloji & 281.543 & 2470 & 0,877 & 24 \\
\hline Biyoloji ve biyokimya & 532.887 & 4413 & 0,828 & 27 \\
\hline Fizik & 841.932 & 6043 & 0,718 & 31 \\
\hline Ekonomi ve işletme & 145.930 & 1015 & 0,696 & 26 \\
\hline Mikrobiyoloji & 151.174 & 1033 & 0,683 & 31 \\
\hline Psikiyatri ve psikoloji & 221.484 & 1419 & 0,641 & 21 \\
\hline Sosyal bilimler & 385.211 & 2119 & 0,550 & 28 \\
\hline İmmünoloji & 118.947 & 596 & 0,501 & 32 \\
\hline Moleküler biyoloji ve genetik & 258.180 & 1225 & 0,474 & 31 \\
\hline Uzay bilimleri & 114.818 & 503 & 0,438 & 39 \\
\hline
\end{tabular}

Not: Alanlar katkı oranlarına göre sıralanmaktadır.

Alanlar içinde katkı oranlarına göre sıralama yapıldığında Türkiye'nin klinik tıp alanında 13., ziraat alanında ise 14. sırada yer aldığı görülmektedir. Türkiye, en düşük katkı oranına $(\% 0,4)$ sahip olduğu uzay bilimlerinde ise 39 . sırada kendine yer bulmuştur.

Türkiye'nin alanlar bazında yayın başına düşen atıf sayıları ile dünya ortalamaları karşılaştırıldığında, tüm alanlarda dünya ortalamasının altında kalındığı görülmektedir. Şekil 1'de Türkiye'nin dünya ortalamasına en yakın performans gösterdiği beş alan ile en uzak performansa sahip olduğu beş alan sunulmaktadır. Aynı zamanda söz konusu ortalamalar göreli atıf etkisinin hesaplanmasında kullanılmıştır. 


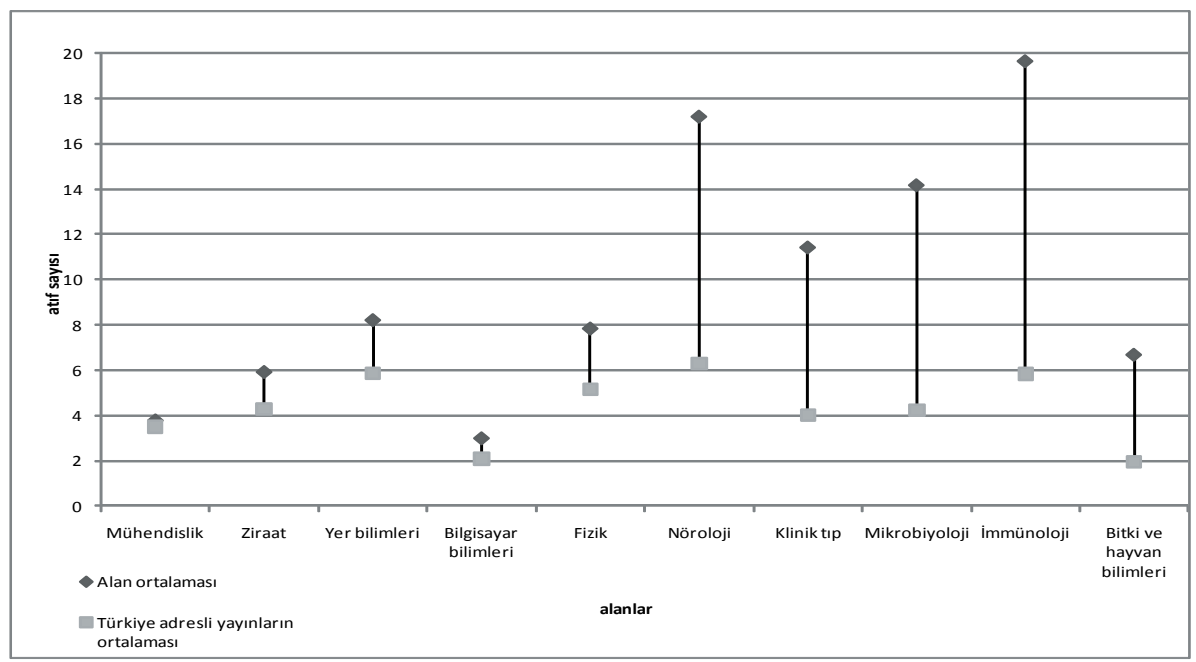

Şekil 1. Yayın başına düşen atıf sayılarına ilişkin dünya ve Türkiye ortalamaları

Türkiye'nin göreli atıf etkisinin en yüksek olduğu alan mühendislik, en düşük olduğu alan bitki ve hayvan bilimleridir (Bkz. Tablo 3). Daha önce yapılmış çalışmada da bu iki alana ilişkin bulgular aynıdır (Al, 2008, s.112). Bununla birlikte araştırmamızdaki Türkiye'nin alanlar bazındaki göreli atıf etkisi sıralaması ile daha önce yapılmış olan çalışmadaki göreli atıf etkisi sıralaması büyük oranda benzeşmektedir (Spearman's $r h o=0,899, p<0,01)$. Buna göre Türkiye'nin göreli atıf etkisi yüksek alanları ile düşük alanlarının zaman içinde fazla değişim göstermediği görülmektedir. Sadece ziraat alanında belirgin bir değişim görülmektedir. Daha önceki çalışmada onuncu sırada (göreli atıf etkisi: 0,46) yer alan ziraat alanı, çalışmamız kapsamındaki verilere göre en yüksek ikinci göreli atıf etkisine $(0,72)$ sahiptir. Öte yandan sosyal bilimler ve mikrobiyoloji dışındaki tüm alanlarda Türkiye'nin göreli atıf etkisi artış göstermiştir. Daha önce sosyal bilimlerin göreli atıf etkisi 0,49 iken 0,44'e düşmüş, mikrobiyolojide ise bu oran 0,31'den 0,30'a inmiştir.

Bitki ve hayvan bilimleri alanının Türkiye'nin en düşük göreli atıf etkisine sahip alanı olmasının gerekçesi olarak Türkiye adresli en çok yayın yapılan derginin Türkiye orijinli bir dergi olması (Turkish Journal of Veterinary \& Animal Sciences) ve bu derginin etkisinin alan içindeki düşüklüğü gösterilmektedir (Al, 2008, s.112). Benzer şekilde eğer son dönemde atıf dizinlerine alınan Türkiye orijinli dergiler sadece ülkenin yayın sayısını artıran, fakat bünyesindeki makaleler atıf almadığı için ortalama etkiyi düşüren bir görünüme sahip olurlarsa, söz konusu alanlarda Türkiye'nin göreli atıf etkisi olumsuz yönde etkilenecektir. 
Tablo 3. Türkiye'nin alanlar bazında göreli atıf etkisi

\begin{tabular}{|l|r|r|r|}
\hline Alan & $\begin{array}{c}\text { Yayın başına düşen } \\
\text { atıf sayısı (dünya) }\end{array}$ & $\begin{array}{c}\text { Yayın başına } \\
\text { düs atıf sayısı } \\
\text { (Türkiye) }\end{array}$ & $\begin{array}{c}\text { Göreli atıf } \\
\text { etkisi }\end{array}$ \\
\hline Mühendislik & 3,80 & 3,50 & 0,92 \\
\hline Ziraat & 5,94 & 4,29 & 0,72 \\
\hline Yer bilimleri & 8,23 & 5,87 & 0,71 \\
\hline Bilgisayar bilimleri & 3,01 & 2,08 & 0,69 \\
\hline Fizik & 7,86 & 5,15 & 0,66 \\
\hline Farmakoloji & 10,61 & 6,58 & 0,62 \\
\hline Matematik & 2,90 & 1,72 & 0,59 \\
\hline Malzeme bilimi & 5,56 & 3,20 & 0,58 \\
\hline Kimya & 9,37 & 5,17 & 0,55 \\
\hline Moleküler biyoloji ve genetik & 23,58 & 11,82 & 0,50 \\
\hline Ekonomi ve işletme & 4,88 & 2,46 & 0,50 \\
\hline Sosyal bilimler & 3,96 & 1,75 & 0,44 \\
\hline Psikiyatri ve psikoloji & 9,46 & 3,99 & 0,42 \\
\hline Çevre ve ekoloji & 9,32 & 3,85 & 0,41 \\
\hline Uzay bilimleri & 12,75 & 4,94 & 0,39 \\
\hline Biyoloji ve biyokimya & 15,49 & 5,93 & 0,38 \\
\hline Nöroloji & 17,22 & 6,28 & 0,36 \\
\hline Klinik tıp & 11,44 & 4,00 & 0,35 \\
\hline Mikrobiyoloji & 14,19 & 4,23 & 0,30 \\
\hline İmmünoloji & 19,67 & 5,83 & 0,30 \\
\hline Bitki ve hayvan bilimleri & 6,70 & 1,95 & 0,29 \\
\hline
\end{tabular}

Not: Alanlar göreli atıf etkisi oranlarına göre sıralanmaktadır.

Şekil 2'de en çok yayın yapan on ülke ve Türkiye'nin alanlar bazındaki göreli atıf etkisi sunulmaktadır. Buna göre ABD, İngiltere ve Kanada tüm alanlarda dünya ortalamasının üzerinde göreli atıf etkisine sahipken; Çin Halk Cumhuriyeti ve Türkiye tüm alanlarda dünya ortalamasının altında kalmıştır. Almanya, Fransa ve Avustralya dörder alanda 1'den düşük göreli atıf etkisine sahiptir. Almanya'nın 1'den düşük göreli atıf etkisine sahip olduğu alanlar; ziraat, ekonomi ve işletme, sosyal bilimler, psikiyatri ve psikoloji; Fransa'nınkiler ekonomi ve işletme, sosyal bilimler, psikiyatri ve psikoloji, biyoloji ve biyokimya, Avustralya'nınkiler ise moleküler biyoloji ve genetik, ekonomi ve işletme, psikiyatri ve psikoloji, nörolojidir. Görüldüğü üzere ekonomi ve işletme ile psikiyatri ve psikoloji alanları için söz konusu üç ülkede de dünya ortalamasının altında bir atıf performansı olduğu saptanmıştır. Zaten Şekil 2'de yer alan 11 ülke içerisinde sadece üç ülkenin göreli atıf etkisi ekonomi ve işletme ile psikiyatri ve psikoloji alanlarında 1'den yüksektir. ABD'nin katkısı psikiyatri ve psikoloji alanında \%52; ekonomi ve işletme alanında ise \%44'tür. Bununla birlikte ABD'nin göreli atıf etkisi ekonomi ve işletme alanında 1,54; psikiyatri ve psikoloji alanında 1,20'dir. Bir ülke tarafından hem bu derece yüksek katkı yapılması, hem de bu katkının sadece yayın bazında kalmayıp atıfa da etki etmesi sonucunda bu iki alana yönelik olarak diğer ülkelerin göreli atıf etkisi düşük çıkmaktadır. 
En fazla yayın yapan diğer ülkelere bakıldığında, Japonya'da 1'den düşük göreli atıf etkisi olan alan sayısının 15, İspanya'da 14, İtalya'da ise 12 olduğu görülmektedir. Türkiye'nin az farkla da olsa Japonya'dan iki alanda daha yüksek göreli atıf etkisine sahip olduğu belirlenmiştir. Bu alanlar Türkiye'nin göreli atıf etkisinin en yüksek olduğu alan olan mühendislik ile Japonya'nın en düşük göreli atıf etkisine sahip olduğu alan olan ekonomi ve işletme alanlarıdır. Özellikle mühendislik alanındaki bu sonuç nedenleri çok net olarak görünmemesine karşın oldukça ilgi çekicidir.

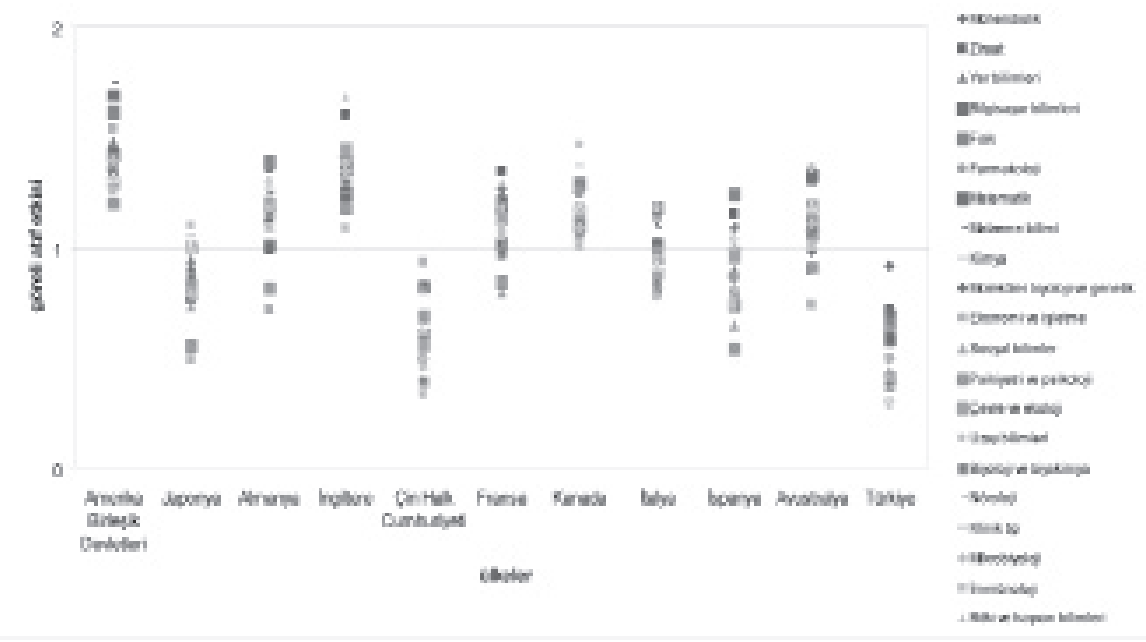

Şekil 2. En fazla yayın yapan ülkeler ve Türkiye'nin göreli atıf etkisi

Çalışmamızda, Türkiye'nin alanlar bazında yayın sayısına göre sıralamadaki yeri ile göreli atıf etkisine göre sıralamadaki yeri de araştırılmıştır. Bir önceki çalışmayla karşılaştırıldığında, sadece farmakolojide Türkiye'nin yayın sayısı sıralamasının değişmediği, diğer tüm alanlarda yayın sayısı sıralaması bakımından daha da yukarılara çıkıldığı görülmüştür. Aynı durum göreli atıf etkisi sıralaması için ise geçerli değildir. Türkiye 14 alanda bir önceki araştırmada elde edilen sıralamadan daha geride bir sıralamaya sahiptir (Bkz. Tablo 4). Ziraat, fizik, farmakoloji, ekonomi ve işletme, biyoloji ve biyokimya, klinik tıp, bitki ve hayvan bilimleri alanları göreli atıf etkisine göre yapılan sıralamada geçmiş döneme kıyasla Türkiye'nin daha ön sıralarda kendine yer bulduğu alanlardır.

Alanlar tek tek incelendiğinde, bazı alanlarda göreli atıf etkisi sıralamalarında Türkiye'nin son sıralarda yer aldığı görülmektedir. Örneğin, immünoloji ile bitki ve hayvan bilimleri alanlarında Türkiye'den daha düşük göreli atıf etkisine sahip sadece ikişer ülke (immünolojide Bulgaristan ve İran; bitki ve hayvan bilimlerinde Pakistan ve İran) bulunmaktadır. Mikrobiyolojide ise bu sayı üçtür (Tunus, Ukrayna ve İran). Türkiye en çok yayın yaptığı alan olan klinik tıpta ise göreli atıf etkisi sıralamasında 107 ülke içerisinde 100. sırada yer almaktadır. 
Tablo 4. Alanlar bazında yayın sayısı ve göreli atıf etkisine göre Türkiye'nin durumu

\begin{tabular}{|c|c|c|c|c|}
\hline Alan & $\begin{array}{c}\text { Yayın } \\
\text { sayılarına } \\
\text { göre } \\
\text { Türkiye'nin } \\
\text { sıralamadaki } \\
\text { yeri } \\
(1995-2005)\end{array}$ & $\begin{array}{c}\text { Yayın } \\
\text { sayılarına } \\
\text { göre } \\
\text { Türkiye'nin } \\
\text { sıralamadaki } \\
\text { yeri } \\
(1999-2009)\end{array}$ & $\begin{array}{c}\text { Göreli atıf } \\
\text { etkisine } \\
\text { göre } \\
\text { Türkiye'nin } \\
\text { sıralamadaki } \\
\text { yeri } \\
(1995-2005)\end{array}$ & $\begin{array}{c}\text { Göreli atıf } \\
\text { etkisine göre } \\
\text { Türkiye'nin } \\
\text { sıralamadaki } \\
\text { yeri } \\
\text { (1999-2009) }\end{array}$ \\
\hline Mühendislik & 21 & 16 & 27 & 39 \\
\hline Ziraat * & 18 & 14 & 76 & 53 \\
\hline Yer bilimleri & 28 & 25 & 62 & 64 \\
\hline Bilgisayar bilimleri & 28 & 26 & 48 & 57 \\
\hline Fizik * & 35 & 31 & 61 & 59 \\
\hline Farmakoloji * & 20 & 20 & 65 & 56 \\
\hline Matematik & 35 & 25 & 60 & 64 \\
\hline Malzeme bilimi & 23 & 19 & 58 & 59 \\
\hline Kimya & 25 & 21 & 59 & 60 \\
\hline Moleküler biyoloji ve genetik & 36 & 31 & 56 & 63 \\
\hline Ekonomi ve işletme * & 31 & 26 & 63 & 57 \\
\hline Sosyal bilimler & 35 & 28 & 81 & 88 \\
\hline Psikiyatri ve psikoloji & 27 & 21 & 68 & 73 \\
\hline Çevre ve ekoloji & 27 & 23 & 90 & 92 \\
\hline Uzay bilimleri & 42 & 39 & 61 & 62 \\
\hline Biyoloji ve biyokimya * & 31 & 27 & 88 & 71 \\
\hline Nöroloji & 27 & 24 & 68 & 71 \\
\hline Klinik tıp * & 14 & 13 & 102 & 100 \\
\hline Mikrobiyoloji & 39 & 31 & 81 & 85 \\
\hline İmmünoloji & 36 & 32 & 87 & 88 \\
\hline Bitki ve hayvan bilimleri * & 28 & 20 & 104 & 103 \\
\hline
\end{tabular}

Not: Alanlar bu çalışmada elde edilen göreli atıf etkisi oranlarına göre sıralanmaktadır. * olan alanlar göreli atıf etkisine göre Türkiye'nin sıralamadaki yerinin yukarıya çıktığı alanlardır.

Türkiye, en yüksek göreli atıf etkisine sahip olduğu mühendislikte 27. sıradan 39. sıraya düşmesine karşın, Çin Halk Cumhuriyeti, Japonya, Güney Kore, Tayvan, Hindistan, Rusya gibi ülkeleri geride bırakma başarısını göstermiştir (Bkz. Şekil 3). Sayıları az olmakla beraber az sayıdaki yayınına karşılık çok sayıda atıf almış olan ülkelerin sıralamada Türkiye'yi gerilere attığı gözlenmektedir. Öte yandan aynı alanda, yayın sayıları Türkiye'den birkaç kat fazla olan Fransa, Kanada, İtalya gibi ülkelerin ortalama atıf sayılarının da yüksek olduğu unutulmamalıdır. Buradan hareketle yayın sayılarının fazla olması göreli atıf etkisini düşüren bir unsur olarak görülmemelidir. 


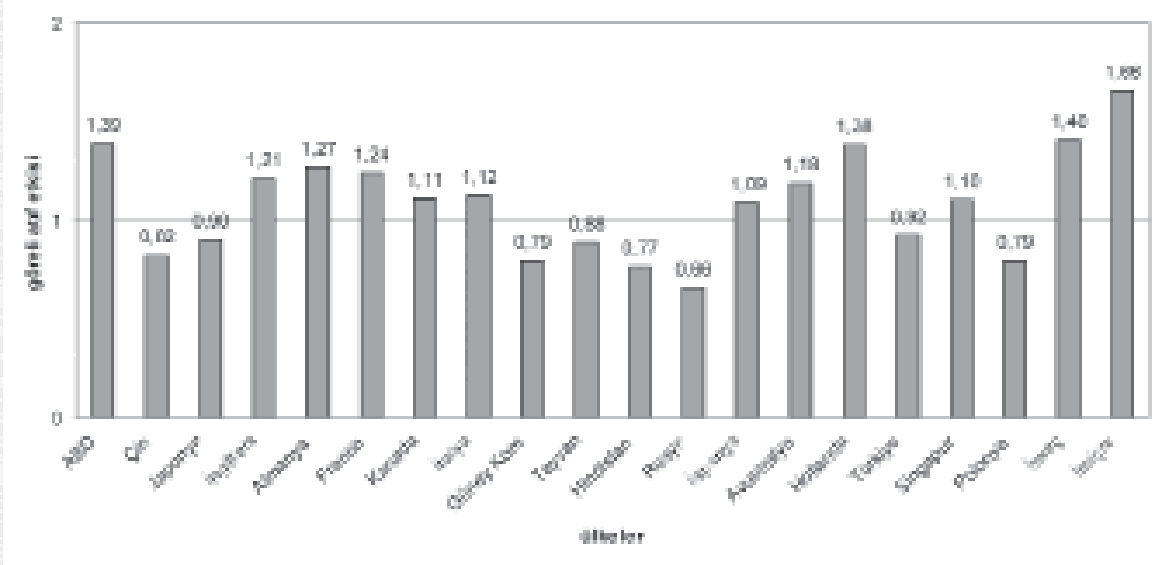

Şekil 3. Mühendislik alanında en fazla yayın yapan ülkelerin göreli atıf etkisi

\section{Sonuç}

Bu çalışma, farklı alanlarda Türkiye'nin farklı yayın ve atıf performansı içinde olduğunu ortaya koymaktadır. Türkiye kimi alanlarda bilimde ileri sayılan ülkelerle neredeyse başa baş performans gösterirken, genellikle atıf sayılarının dikkate alınarak değerlendirme yapıldığı durumlarda olumsuz bir görüntü ortaya çıkmaktadır. Türkiye'nin bilim camiası içinde saygın bir yer edinmesinin tek yolu literatüre yapılan katkıyı artırmak olarak algılanmamalıdır. Bu bağlamda ilgili alanlarda dikkat çekici ve yenilik taşıyan çalışmaların diğer çalışmalardan ayrılarak desteklenmesi gerekmektedir. Aksi takdirde Türkiye dünyada en çok yayın üreten ülke konumuna dahi ulaşsa bunun fazla bir anlamı olmayacaktır.

Ülkeler arasında yapılan karşılaştırmalarda, Türkiye'nin göreli atıf etkisine göre oluşturulmuş sıralamadaki yerinin, yayın sayılarına göre olan sıralamadaki yerinden oldukça geride olduğu ortaya çıkmıştır. Buna paralel olarak ES/ tarafından belirlenmiş araştırma alanlarının tamamında Türkiye'nin yayın başına düşen atıf sayısı dünya alan ortalamasının altındadır. Bu durum Türkiye'nin evrensel düzeyde bilime katkısının büyük oranda yayın sayısındaki artış konusunda olduğunu açıkça ortaya koymaktadır.

Ülkelerin belirli alanlarda uzmanlaştıkları bilinen bir konudur. Bu durum ES/'deki alanlara göre Türkiye'nin dünya literatüründeki payı incelendiğinde de net bir şekilde görülmektedir. Klinik tıp ve ziraat alanlarında katkı oranı \%2'yi geçerken, birçok alanda Türkiye'nin dünya literatürüne katkısı oldukça düşük kalmıştır. Örneğin, birçok ülkenin bilim politikalarında öncelikli alanlar olan moleküler biyoloji ve genetik ile uzay bilimleri alanlarında Türkiye alan literatürüne çok az katkıda bulunan bir ülke konumundadır. İlk olarak bu alanlarda etkin ülkelerle işbirliği içinde yürütülecek çalışmalar ile belirli bir 
altyapı sağlanması hedeflenmelidir.

Bilimsel yayın faaliyetlerinin yoğun olarak üniversite ortamında gerçekleştirildiği düşünüldüğünde, üniversitelerin ürettikleri yayınları sorgulayıcı bir yapı içinde olmaları gerekmektedir. Hangi amaçla yayın yapıldığı ve yapılan yayınların niteliğinin ne olduğu üzerinde oldukça düşünülmesi gereken konulardır. Bu bağlamda verimlilik olgusunun sadece yayın sayısı ile ölçülmemesi gerekmektedir. Türkiye'nin bilimsel başarıyı yayın sayısına endeksli olarak ölçmeye devam etmesi, ülkemizin yayın sayısı dışındaki göstergelerde ön sıralarda yer almasının önündeki en büyük engeldir.

\section{Kaynakça}

Al, U. (2008). Türkiye'nin bilimsel yayın politikası: Atıf dizinlerine dayalı bibliyometrik bir yaklaşım. Yayımlanmamış doktora tezi, Hacettepe Üniversitesi, Ankara.

Björneborn, L. (2004). Small-world link structures across an academic web space: A library and information science approach. Yayımlanmamış doktora tezi, Royal School of Library and Information Science, Copenhagen.

Braun, T. (1999). Bibliometric indicators for the evaluation of universities - intelligence from the quantitation of the scientific literature. Scientometrics, 45(3), 425-432.

Braun. T., Glänzel, W. ve Schubert, A. (1987a). One more version of the facts and figures on publication output and relative citation impact of 107 countries 1978-1980. Scientometrics, 11(1-2), 9-15.

Braun. T., Glänzel, W. ve Schubert, A. (1987b). One more version of the facts and figures on publication output and relative citation impact in the life sciences and chemistry 1978-1980. Scientometrics, 11(3-4), 127-140.

Braun. T., Glänzel, W. ve Schubert, A. (1987c). One more version of the facts and figures on publication output and relative citation impact in physics and mathematics 1978-1980. Scientometrics, 12(1-2), 3-16.

Braun. T., Glänzel, W. ve Schubert, A. (1988a). The newest version of the facts and figures on publication output and relative citation impact of 100 countries 1981-1985. Scientometrics, 13(5-6), 181-188.

Braun. T., Glänzel, W. ve Schubert, A. (1988b). The newest version of the facts and figures on publication output and relative citation impact in the life sciences and chemistry 1981-1985. Scientometrics, 14(1-2), 3-15.

Braun. T., Glänzel, W. ve Schubert, A. (1988c). The newest version of the facts and figures on publication output and relative citation impact in physics. engineering and mathematics 1981-1985. Scientometrics, 14(5-6), 365-382.

Braun. T., Glänzel, W. ve Schubert, A. (1989). The newest version of the facts and figures on publication output and relative citation impact. A collection of relational charts. 1981-1985. Scientometrics, 15(1-2), 13-20. 
Butler, L. (2003). Explaining Australia's increased share of ISI publications - the effects of a funding formula based on publication counts. Research Policy, 32(1), 143-155.

Czajbók, E., Berhidi, A., Vasas, L. ve Schubert, A. (2007). Hirsch-index for countries based on Essential Science Indicators data. Scientometrics, 73(1), 91-117.

Glänzel, W., Thijs, B. ve Schlemmer, B. (2004). A bibliometric approach to the role of author selfcitations in scientific communication. Scientometrics, 59(1), 63-77.

Ingwersen, P. (2000). The international visibility and citation impact of Scandinavian research articles in selected social science fields: The decay of a myth. Scientometrics, 49(1), 3961.

Karasözen, B. ve Bayram, Ö. G. (2007). 1997-2006 Türkiye bilim göstergeleri analizi. 24 Temmuz 2008 tarihinde http://www.yok.gov.tr/bilimselgostergeler/bilimselanaliz.pdf adresinden erişildi.

Katz, J. S. (2000). Scale-independent indicators and research evaluation. Science and Public Policy, 27(1), 23-36.

King, C. (2009). Despite slide in world share, U.S. impact still looks strong. 14 Haziran 2009 tarihinde http://sciencewatch.com/ana/fea/09janfebFea/ adresinden erişildi.

Leydesdorff, L. (2005). Evaluation of research and evolution of science indicators. Current Science, 89(9), 1510-1517.

May, R. M. (1997). The scientific wealth of nations. Science, 275(5301), 793-796. 15 Haziran 2009 tarihinde http://www.sciencemag.org/cgi/content/full/275/5301/793 adresinden erişildi.

Persson, O., Luukkonen, T. ve Hälikkä, S. (2000). A bibliometric study of Finnish science. 15 Haziran 2009 tarihinde http://www.vtt.fi/inf/julkaisut/muut/2000/wp48.pdf adresinden erişildi.

SCI-Bytes. (2003). Science in the United States, 1998-2002. 14 Haziran 2009 tarihinde http:// in-cites.com/research/2003/april_21_2003-2.html adresinden erişildi.

Tague-Sutcliffe, J. (1992). An introduction to informetrics. Information Processing and Management, 28(1), 1-3.

ULAKBIM. (2009). UBYT istatistikleri. 15 Haziran 2009 tarihinde http://www.ulakbim.gov.tr/cabim/ ubyt/stats/index.uhtml adresinden erişildi. 